\title{
Tamamlayıcı Beslenme: Avrupa Pediatrik Gastroenteroloji, Hepatoloji ve Beslenme (ESPHGAN) Birliği Komitesi Görüş Raporu
}

\author{
Complementary Feeding: A Position Paper by the European Society for Paediatric \\ Gastroenterology, Hepatology, and Nutrition (ESPGHAN) Committee on Nutrition
}

Prof. Dr. Ayla Gülden Pekcan ${ }^{1}$

Dünya Sağlık Örgütü (WHO), 2002 yılnda tamamlayıcı beslenmeyi (TB) “Tamamlayıcı beslenme, anne sütünün bebeğin beslenme gereksinimlerini karşılamada tek başına artık yeterli olamadı̆̆ında başlanan süreçtir” diye tanımlamaktadır (1). Tamamlayıcı besinlere hem beslenme hem de gelişimsel nedenlerle gereksinme duyulduğu ve anne sütünden aile besinlerine geçişte önemli bir basamak olduğu belirtilmiştir (2). Tamamlayıcı beslenme dönemi hızlı büyümenin ve gelişmenin olduğu, bebeklerin besin ögesi yetersizliklerine ve aşırı alımlara duyarlılığının oluştuğu, yeni besinlere, tatlara ve beslenme deneyimlerine maruziyet ile önemli değişikliklerin görüldüğü bir dönemdir (2).

ESPHGAN 2008 yllında (3) yayınladığı sağlıklı zamanında doğmuş bebekleri hedefleyerek belirttiği tamamlayıcı beslenme ile ilgili görüşlerini, 2017 yllında gluten ve alerjenik besinlere başlamada yeni kanıtlar ve randomize kontrollü çalışmalardan elde edilen veriler ışığında güncellemiştir (2). Yayın "Tamamlayıc Beslenme: Avrupa Pediatrik Gastroenteroloji, Hepatoloji ve Beslenme (ESPHGAN) Komitesi Görüş Raporu” olarak yayınlanmıştır ve yayın tamamlayıcı beslenmenin farklı yönlerini ele alan dört bölümden oluşmuştur (2). Raporda birinci bölümde tamamlayıcı beslenmeye başlama zamanı (gelişme açısından hazır olma, beslenme yönünden yeterlilik ve sağlık üzerine etkileri dikkate alınarak), ikinci bölümde tamamlayıcı besinlerin içeriği (besin ögeleri gereksinmesi ve sağlık üzerine etkileri dikkate alınarak), üçüncü bölümde beslenme yöntemi ve dördüncü bölümde ise özel beslenme uygulamalarına yer verilmiştir.

$\mathrm{Bu}$ derleme yazı ESPHGAN tarafindan 2017 yllında yayınlanan tamamlayıcı beslenme raporu görüşleri temel alınarak hazırlanmış (2), Türkiye uygulamaları irdelenmiş, editör yorumlarına yer verilmiştir.

\section{Tanımlar}

Sadece anne sütü ile beslenme: WHO, "sadece anne sütü ile beslenmeyi bebeğin damla veya şurup olarak vitamin, mineral desteği ve ilaçlar dışında diğer sıvı veya katı besinleri içermeden sadece anne sütü verilmesi” olarak tanımlamaktadır (2).

Tamamlayıcı besin: Anne sütü dışında, doğumdan itibaren başlanan her besin ve/veya mama tamamlayıcı besin olarak tanımlanmaktadır. Anne sütü ile beslenmenin önemini vurgulamak ve emzirmeyi desteklemek için bebek ve devam mamaları tamamlayıcı besin kapsamında değerlendirilmektedir. Ancak ESPHGAN (2) ve Avrupa Gıda Güvenliği Otoritesi (EFSA-European Food Safety Authority) (4) son yayınlarında Avrupa'da birçok bebeğin sıklıkla doğumdan itibaren tek başına anne sütü veya anne sütü ile bebek mamasinın birlikte verilerek bebeğin beslendiği vurgulanmış, bu durumun ise kafa karıştırıcı olduğu belirtilmiştir.

1. Beslenme ve Diyet Dergisi • E-posta: info@beslenmevediyetdergisi.org • ๑ https://orcid.org/0000-0002-2037-3037 


\section{Tamamlayıcı Beslenmeye Başlama Zamanı}

WHO, sadece anne sütü ile beslenmenin 6 ay olmasını ve 6. aydan sonra anne sütü ile birlikte tamamlayıcı besinlere başlanmasını ve emzirmenin 2 yaşına kadar sürdürülmesini önermektedir. $\mathrm{Bu}$ öneride bebek mamaları tamamlayıcı besin olarak kabul edilmektedir.

ESPHGAN ise bebek mamalarını tamamlayıcı besin dışında tutmayı istemesine karşın, yayınlarda farklı tanımların kullanıldığı ve daha çok katı besinlere başlamadan çok, sadece anne sütü ile beslenmenin süresi üzerinde durulduğunun görüldüğü belirtilmiştir. Bu doğrultuda tamamlayıcı besinlere 4 . aydan önce ( $<17$ hafta) ve 6 . aydan sonra ( $>26$ hafta) başlanmamasının gerektiği belirtilmiştir $(2,3)$.

Tamamlayıcı besinlere başlama zamanı ile ilgili kanıtların genellikle yetersiz olduğu, tamamlayıcı beslenmenin ülkeden ülkeye besinin bulunabilirliği ve kültürel etmenlere bağlı olarak değişebildiği ileri sürülmüştür. İsveç ve Hollanda gibi birçok ülkede bebeklere 4-6. aylar arasinda “deneme besinler" veya "küçük tadımlık besinler” verilebilmektedir. Diğer bazı ülkeler ise tamamlayıcı besinlere başlamayı 4-6. aylar arasında önermektedir.

Türkiye'de bebeklerin 6 ay süre ile sadece (tek başına) anne sütü ile beslenmesi, 6. aydan sonra tamamlayıcı besinlere başlanması, tamamlayıc besinlerle birlikte anne sütü ile beslemenin 2 yaşa kadar sürdürülmesi tüm bebeklerle ilintili ulusal programlarda yer almakta ve desteklenmektedir.

Türkiye'de bebek ve devam formulalart ile bebek ve çocuk ek gidaları için tebliğler yayınlanmıştır. Bunlar, "Türk Gıda Kodeksi Bebek Formülleri Tebliği (Tebliğ No: 2014/31, Resmi Gazete:15 Ağustos 2014)”, “Türk Gıda Kodeksi Devam Formülleri Tebliği (Güncellenme Tarihi: 2014/32; Resmi Gazete:15 Ağustos 2014)" ve "Türk Gıda Kodeksi Bebek ve Küçük Çocuk Ek Gıdaları Tebliği'dir (Tebliğ No: 2007/50) (https://www.tarim.gov. tr/Mevzuat/Turk-Gida-Kodeksi).
Bebek maması bebeklerin yaşamlarının ilk ayları boyunca, uygun tamamlayıc beslenme ile tanışıncaya kadar özel beslenme ihtiyaçlarını karşllayan ürünleri (5) ve Devam maması özel beslenme amaclyla, sadece anne ve çocuk beslenmesi üzerinde uzmanlaşmış tarafsız bir sağlık çalışanı tarafindan bebeğin büyüme ve gelişim ihtiyaçlarına dayanarak farklı bir ay önerilmediği takdirde altı aydan itibaren bebeklerin giderek çeşitlenen diyetlerindeki başlica sıvı alımını oluşturan ürünleri (6) ifade eder şeklinde tanımlanmaktadır.

Isşlenmiş Tahıl Bazlı Ek Gıdalar "Temel olarak bir veya daha fazla öğütülmüş tahıllardan ve/veya baklagillerden ve/veya kök ve/veya gövdelerinde nişasta içeren bitkilerden hazırlanan, bebeklerin beslenmesinde anne sütü veya bebek formülleri veya devam formüllerinin tamamlayıcısı olarak veya küçük çocukları (12-36 ay arası yaş grubu) ileri yaşlardaki günlük diyetlerine alıştırmak için kullantlan ek gıdaları", Tahıl Bazlı Olmayan Ek Gıdalar ise "İşlenmiş tahıl bazlı gıdalar dışında kalan, bebek ve küçük çocukların (12-36 ay) beslenmesinde kullanılan ek gidalarl" ifade etmektedir (7).

Altı ay süre ile sadece anne sütünün verilmesi arzu edilen hedeftir. Yüksek gelir düzeyindeki ülkelerde yaşayan ve 6 ay sadece anne sütü ile beslenen bebekler ile 3 ay sadece anne sütü verilenler kıyaslandığında gastrointestinal enfeksiyon riskinin azaldığı belirlenmiştir. Tamamlayıcı besinlere (anne sütü veya bebek maması dışında tüm katı besinler ve sıvı besinlere) başlama 6 . aydan fazla geciktirilmemeli ve kesinlikle 4 . aydan önce başlanmamalıdır. Ancak sadece anne sütü ile beslenmenin en azından 4 ay (17 hafta, yaşamın 5 . ayının başlangıcı) süre verilmesi desteklenmelidir. Annenin gebelik döneminde bebeğini anne sütü ile beslemeye hazırlanması, gebelik döneminde yeterli ve dengeli beslenmesi, uygun vücut ağırlı̆̆ kazanımı yaklaşımları laktasyon döneminde sağllkl emzirme için büyük önem taşımaktadır. 
Eldeki veriler 4. ayda bebeklerin renal ve gastrointestinal işlevlerin tamamlayıcı besinlerdeki besin ögelerini metabolize edecek olgunluğa eriştiğini göstermektedir. Bebekler 6. ayda kaşıkla püre şeklinde verilen tamamlayıcı besinleri güvenle yeme ve yutabilme becerisine sahiptir. Dokuzuncu aydan itibaren bebekler kendi kendine yiyebilme, iki elini kullanarak bardaktan içebilme, bazı uygulamalar sonucu (lokma büyüklüğünde kesme, kaşıkla veya elle parmak besinler hazırlama) aile yemeklerini tüketebilme kapasitesine sahiptir. Yarı katı lokma besinlere 9-10. aylarda başlanmadığında ileri yaşlarda yeme güçlükleri görülebilmekte ve önemli besin gruplarının (örneğin sebze ve meyveler) tüketimi zorlaşmaktadır.

\section{Sadece Anne Sütünün Beslenme Yönünden İçeriği ve Yeterliliği}

Altıncı ayına kadar bebeklerin günlük alması önerilen besin ögesi miktarları sağlıklı, zamanında doğmuş ve anne sütü ile beslenerek normal büyüme gösteren bebeklere göre hazırlanarak önerilmektedir. Yeterli ve dengeli beslenen annelerin anne sütlerinin 6. ayına kadar bebeğin enerji, protein, vitamin ve mineraller (ilk haftada $\mathrm{K}$ vitamini ve $\mathrm{D}$ vitamini dışında) gereksinmesini karşılayabilmekte ve WHO büyüme eğrilerine uygun büyüme sağlanmaktadır. Bebeklerde demir alımı ve demir depoları da birçok etmene bağlıdır. Düşük doğum ağırlıklı, prematüre ve demir açısından risk taşıyan bebeklerin değerlendirilmesi ve gerektiğinde destek verilmesi önerilmektedir. Türkiye'de bebeklere doğumdan sonra ilk hafta içerisinde $400 \mathrm{IU}$ (10 mcg) D vitamini desteği ile 4. aydan itibaren günde $10 \mathrm{mg}$, düşük doğum ağtrlıklı ve prematüre bebeklere ise 2. aydan itibaren $2 \mathrm{mg} / \mathrm{kg} / g u ̈ n$ demir desteği verilmesi ulusal program olarak yürütülmektedir.

\section{Öneriler}

- Özel bazı tamamlayıcı besinlerin önerilmesinde toplumun beslenme alışkanlıkları ve gelenekleri dikkate alınmalıdır.
- Tamamlayıcı beslenme ile birlikte anne sütünün verilmesine devam edilmelidir.

- İnek sütü demir kaynağı olarak fakirdir ve inek sütünün fazla tüketimi aşırı protein, yağ ve enerji alımına neden olmaktadır. İnek sütünün 12. aydan önce içecek olarak bebeklere verilmemesi önerisi yaygin olarak vurgulanmaktadır. Ancak, 9-10. aylardan itibaren bebeklerin tamamlayıcı besinlerinin hazırlanmasında az miktarlarda inek sütünün kullanılabileceği de belirtilmektedir. Kullanılacak miktarın ise 500 $\mathrm{mL} /$ gün üzerine çıkmaması önerilmektedir (3). $\mathrm{Bu}$ doğrultuda kullanılacak miktarın belirlenebilmesi için mutlaka bir diyetisyenle görüşülmesi gerekmektedir. Bebeğin beslenme örüntüsüne (anne sütü alma vb. durumlar) ve aile olanaklarina göre diyetisyen önerisi önem taşımaktadır.

Alerji

- Alerjenik besinlerin tamamlayıcı besinlere başlandiktan sonra, 4-6. aydan (<17->26 hafta) itibaren verilmesi alerji riskini (yumurta, ballk, yağlı tohumlar, vb.) azaltmaktadır.

- Yer fistığı alerjisi için yüksek risk taşıyan bebeklere yer fistığı (sürülebilir yağ olarak) 4 ile 6. aylar arasında başlanmalı ve sağlık çalışanı tarafından yakından izlenmelidir. Türkiye'de beslenme örüntüsünde sürülebilir yer fistığl kullanımı sık ve yaygin görülen bir uygulama değildir. Yer fistığ üretilen bölgelerde bu uyarı dikkate alınmalıdır.

\section{Çölyak Hastalı̆̆ı}

- Çölyak hastalığı genetik olarak duyarlı olan bireylerde gluten alımı ile bağırsaklar ve diğer organları etkileyen otoimmün reaksiyonla sonuçlanan bir hastalıktır. Dünya'nın birçok ülkesinde genel popülasyonun yaklaşık \%13’ünü etkileyen bir sorundur. Bebek besleme uygulamalarının özellikle anne sütü ve glutene başlanma yaşının etkileri üzerinde tartışmalar devam etmektedir. 
- ESPHGAN 2008 yılında yayınlara dayalı olarak gluten içeren besinlere başlamanın erken $(<4$ ay, $<17$ hafta) ve geç ( $\geq 7$ ay, $>26$ hafta) olmasının önlenmesi gerektiğini belirtmiş ve önemini vurgulamış, bebek anne sütü alırken gluten verilmesinin çölyak, aynı zamanda tip 1 diyabet hastalığı ile buğday alerjisi riskini azaltacağını ileri sürmüştür (3).

- ESPHGAN 2016 yılında bebeklere gluten başlanmasına ilişkin önerisini güncellemiş ve glutene 4 ile 12. aylar arasında başlanmasını önermiştir. Glutene başanılan ilk hafta içerisinde ve bebeklik dönemi süresince yüksek miktarda gluten verilmesinden kaçınılmasına dikkati çekmiştir. Ayrıca günümüzde henüz gluten için en uygun miktarın belirlenmemiş olduğunu da belirtmiştir (8).

\section{Büyüme ve Vücut Bileşimi}

- Tamamlayıcı beslenme sırasında yüksek protein alımının fazla kilolu veya obez olma riskini özellikle genetik olarak yatkın çocuklarda arttırabileceği belirtilmektedir. Ortalama proteinin enerjiden gelen oranı \%15'in üzerinde olmamalıdır. Yayınlar katı tamamlayıcı besinlere 4. aydan önce başlanmasının ileri yaşlarda obezite riskini arttırabileceğini göstermektedir. "Avrupa Çocukluk Çağı Obezite Programı” ile gereksinmeden yüksek protein içeren mamalar ile beslenmenin bebeklik ve çocukluk döneminde (erken protein hipotezi) obeziteye neden olduğu belirlenmiştir. Mama ile beslenen bebeklerde anne sütü ile beslenenlere kıyasla vücut ağırlığının kilogramı başına protein alımının \%55-80 daha fazla olduğu saptanmıştır (9).

\section{Tamamlayıcı Besinlerin İçeriği}

- Yağ alımı enerji alımının önemli bir belirleyicisidir. Düşük yağlı diyetin enerji yoğunluğu düşüktür, yüksek yağlı diyet ise diyette çeşitliliği azaltır. EFSA tarafindan 6-12. ayda enerjinin yağdan, linoleik asitten ve alfa-linolenik asitten gelen oranının sirasiyla $\% 40, \% 4$ ve $\% 0.5$ olması ve 100 $\mathrm{mg} / g u ̈ n$ dokozahekzaenoik asit (DHA) alınması önerilmiştir (10,11). Bu doğrultuda 700 kkal gün enerji gereksinmesi olan bir bebeğin günlük enerjisinin yağdan gelen miktarı $280 \mathrm{kkal} / \mathrm{gün}$ (31 g/ gün yă̆) olmall ve $3 \mathrm{~g} /$ gün linoleik asit ve $0.5 \mathrm{~g} / \mathrm{gün}$ omega-3 yağ asitleri içermelidir. DHA alım miktarı ise $100 \mathrm{mg} /$ gün olmalıdır.

- Tüm bebeklere et ürünleri ve/veya demirle zenginleştirilmiş besinler dahil, demirden zengin tamamlayıcı besinler verilmelidir. Altı12 ay için demir gereksinmesi 0.9-1.3 mg/kg/gün veya 6-11 mg/gün önerilmektedir. Anne sütü, et proteinleri, askorbik ve sitrik asitler, fermente sebze ürünleri demirin emilimini arttırırken, kakao, polifenoller, fitatlar, tanenler, diyet posası, kalsiyum ve inek sütü emilimi azaltmaktadır. Uygulanacak strateji topluma, kültürel etmenlere ve bulunabilen besinlere dayalı olmalıdır. Demirden zengin besinler veya bebek/devam mamaları, et gibi demirden zengin besinler veya demir desteği verilebilir.

- Sekizinci ayda >600 mL miktarında inek sütü verilen bebeklerle anne sütü alan bebekler kıyaslandığında ilk grupta yer alan bebeklerin 8. aydan 10 yaşına kadar daha kilolu oldukları belirlenmiştir. İnek sütü verilen bebeklerin daha fazla enerji, protein ve yağ aldıkları rapor edilmiştir.

- Uzun zincirli çoklu doymamış yağ asitleri (LCPUFA) özellikle dokozahekzaenoik asit alımının tamamlayıcı beslenmeye geçişle anne sütü ve LCPUFA eklenmiş mamalarla beslenen çocuklara göre az olduğu da belirtilmiştir.

- Tamamlayıcı besinlere şeker ve tuz eklenmemelidir. Meyve suları veya şekerle tatlandırılmış içeceklerden sakınılmalıdır. Şeker diş çürükleri için risk etmenidir. Gece boyunca bebeğin ağzında biberonla beslenerek uyumasının kariyojenik etkisi bulunmaktadır. Bebeklere 12 aydan önce bal verilmemelidir. 


\section{Beslenme Yöntemi, Tat Gelişimi ve Besin Tercihi}

- Gebelik veya erken bebeklik döneminde özel lezzet ve tatlara maruz kalma ile ileri yaşlarda tatların kabulünün daha kolay sağlandığı belirlenmiştir. Bebeklere besin çeşitliliğine dayalı beslenme uygulanmalı, buruk/acımtırak (bitter) tat içeren yeşil sebzeler dahil, değişik lezzet ve yapıda besinler sunulmalıdir.

- Besinler bebeklerin gelişim aşamalarına bağlı olarak uygun yapı ve kıvamda olmalıdır. Parmak besinlere ve kendi kendine yemeye zamanında başlanmalıdır. Besinlerin uzun süre püre olarak verilmesine devam edilmemeli, bebekler 8-10. aylarda yarı katı lokma besinleri yiyor olmalıdır. Bebekler 12. ayda içecekleri bardaktan içebilmelidir.

- Aileler bebeklerinin açlık ve doygunluk işaretlerine uyma konusunda desteklenmelidir. Bebeklerini rahatlatmak veya ödüllendirmek üzere beslemeleri önerilmemelidir.

- Vegan diyetler ancak uygun tıbbi veya diyetetik danışmanlık yapılarak uygulanabilir. Bebeklere verilen diyetin besin ögesi ve enerji yoğunluğu uygun olmall, yeterli miktarda $\mathrm{B}_{12}$ vitamini, D vitamini, folat, demir, çinko, kalsiyum, n-3 grubu uzun zincirli yağ asitleri, protein ve kalsiyum içermelidir. Aileler diyetin desteklenmesinin önemini anlamalı ve uygulamamanın ciddi sonuçlarını öğrenmelidir.

Sonuç olarak sadece anne sütü ile beslenmenin 6 ay olması ve 6 . aydan sonra anne sütü ile birlikte tamamlayıcı besinlere başlanması ve emzirmenin 2 yaşına kadar sürdürülmesi önerisine uyulmalıdır. Tamamlayıcı besin önerileri toplumun geleneklerine ve beslenme örüntüsüne uygun olarak önerilmeli ve ulusal rehberler oluşturulmalı ve güncel veriler ışığında güncellenmeler yapılmalıdır. Tamamlayıcı besinlere 4 . aydan önce ( $<17$ hafta) ve 6 . aydan sonra (>26 hafta) başlanmamalıdır. Bebeklere çeşitlilik gösteren beslenme örüntüsü sunulmalı, diyet farklı lezzet ve kıvamda, besinleri özellikle sebzeleri de içermelidir.
Alerjenik besinler bebeklere tamamlayıcı besinlere başlanması ( $>4$. ay, $>17$. hafta) ile verilmelidir. Gluten bebeğe 4 ve 7 . aylar arasında başlanmalı, glutenin verildiği ilk haftalarda aşırı miktarda verilmesinden sakınılmalıdır.

\section{KAYNAKLAR}

1. WHO (World Health Organization). Complementary Feeding. Report of the Global Consultation. Geneva, 10-13 December 2001. Summary of Guiding Principles. 2002. Available at: http://www.who.int/nutrition/ publications/ Complementary_Feeding.pdf Accessed April 5, 2018.

2. Fewtrell M, Bronsky J, Campoy C, Domellöf M, Embleton N, Mis NF, et al. Complementary Feeding: A Position Paper by the European Society for Paediatric Gastroenterology, Hepatology, and Nutrition (ESPGHAN) Committee on Nutrition. JPGN 2017;64:119-132.

3. ESPHGAN Committee on Nutrition: Agostoni C, Decsi T, Fewtrell M, Goulet O, Kolacek S, Koletzko B, et al. Complementary feeding: a commentary by the ESPGHAN Committee on Nutrition. J Pediatr Gastroenterol Nutr 2008;46(1):99-110.

4. EFSA Panel on Dietetic Products, Nutrition and Allergies (NDA). Scientific opinion on the appropriate age for introduction of complementary feeding of infants. EFSA J 2009;7:1423.

5. T.C. Gıda, Tarım ve Hayvancılık Bakanlığı, Türk Gıda Kodeksi Yönetmeliği. Türk Gıda Kodeksi Bebek Formülleri Tebliği, Tebliğ No (2014/31). Resmi Gazete:15 Ağustos 2014. Erişim: https://www.tarim.gov.tr/Mevzuat/ Turk-Gida-Kodeksi Erişim Tarihi: 3 Nisan 2018.

6. T.C. Gıda, Tarım ve Hayvancılık Bakanlığı, Türk Gıda Kodeksi Yönetmeliği. Türk Gıda Kodeksi Devam Formülleri Tebliği, Tebliğ No (2014/32). Resmi Gazete:15 Ağustos 2014. Erişim: https://www.tarim.gov.tr/Mevzuat/ Turk-Gida-Kodeksi Erişim Tarihi: 4 Nisan 2018.

7. T.C. Gıda, Tarım ve Hayvancılık Bakanlığı, Türk Gıda Kodeksi Yönetmeliği. Türk Gıda Kodeksi Bebek ve Küçük Çocuk Ek Gıdaları Tebliği, Tebliğ No: 2007/50). Resmi Gazete: 1 Kasım 2007. Erişim: https://www.tarim.gov.tr/ Mevzuat/Turk-Gida-Kodeksi Erişim Tarihi: 4 Nisan 2018.

8. Szajewska H, Shamir R, Mearin L, Ribes-Koninckx C, Catassi C, Domellöf M, et al. Gluten introduction and the risk of coeliac disease: a position paper by the European Society for Pediatric Gastroenterology, Hepatology, and Nutrition. J Pediatr Gastroenterol Nutr 2016;62:507-513. 
9. Koletzko B, Broekaert I, Demmelmair H, Franke J, Hannibal I, Oberle D, et al. Protein intake in the first year of life: a risk factor for later obesity? the EU Childhood Obesity Project. Adv Exp Med Biol. 2005;569:69-79.

10. EFSA Panel on Dietetic Products, Nutrition, and Allergies (NDA). Scientific Opinion on Dietary Reference Values for fats, including saturated fatty acids, polyunsaturated fatty acids, monounsaturated fatty acids, trans fatty acids, and cholesterol. EFSA Journal 2010; 8(3):1461.

11. EFSA NDA Panel (EFSA Panel on Dietetic Products, Nutrition and Allergies). Scientific Opinion on nutrient requirements and dietary intakes of infants and young children in the European Union. EFSA Journal 2013;11(10):3408. 